\title{
Cohesive means in Slovenian spontaneous dialectal conversations ${ }^{1}$
}

\author{
Danila Zuluan Kumar \\ Inštitut za slovenski jezik Frana Ramovša ZRC SAZU, \\ Raziskovalna postaja Nova Gorica, Delpinova 12, SI- 5000 Nova Gorica, \\ DZuljan@zrc-sazu.si
}

\begin{abstract}
V prvem delu prispevka avtorica analizira odnos med besedilno koherenco in kohezijo ter predstavlja delitev kohezivnih sredstev, primerno za njihovo analizo v slovenskih pogovornih besedilih. V drugem delu je predstavljena raba kohezivnih sredstev v slovenskih spontanih narečnih pogovorih. Avtorica podrobneje analizira rabo koreferenčnih sredstev (izpusta zaimka, ponovnih in delnih ponovnih pojavitev, medleksemskih razmerij (so-, proti-, pod- in nadpomenk, sopojavljank, parafraze); elipse (sistemske in nesistemske) ter paralelizma.
\end{abstract}

In the first part the article discusses the relationship between textual coherence and cohesion, then it offers a classification of cohesive means for Slovenian conversational texts. In the second part the article presents the use of cohesive means in spontaneous spoken dialectal conversations. The use of co-reference means, i.e. ellipsis of pronouns, recurrences and partial recurrences, lexical relations (synonyms, antonyms, hypernyms, hyponyms, collocations and paraphrase); ellipsis (systemic and non-systemic) and parallelism are presented in detail.

Ključne besede: besedilna kohezija, kohezivna sredstva, koreferenčna sredstva, elipsa, paralelizem, slovenski spontani narečni pogovori

Key words: textual cohesion, cohesive means, co-reference means, ellipsis, parallelism, Slovenian spontaneous dialectal conversations

${ }^{1}$ The text was written in ZRCola, which was developed by Peter Weiss, Phd., Fran Ramovš Institute of the Slovenian Language, Scientific Research Centre SASA. 


\section{Introduction}

A discourse (or a text as its product) is not a structural unit, like a clause or a sentence. Rather, it is a semantic unit, which means that there exist ties within a text which define it as a semantic whole and distinguish it from a set of unconnected utterances. There are many different ties or connections, some of them implicit (e.g. inferences, ${ }^{2}$ which are based on the shared knowledge of discourse participants), others, however, expressed by lexico-grammatical means. The latter are called cohesive ties.

Cohesion in informal spoken communication is, of course, quite unlike that in formal written texts. One of the major differences between them is that, whereas written language is designed to communicate with someone who does not share the writer's immediate context, and writing therefore tends to be relatively explicit, a casual conversation is typically dependent on the participants' shared knowledge and is thus much more implicit.

The purpose of my paper is to find out what cohesive means build informal dialectal conversations and make them semantic wholes, although when being written, they seem quite chaotic.

\section{Textual cohesion}

Textual cohesion means semantic continuity realized through the use of lexicogrammatical means (Halliday and Hasan 1976: 5; Halliday 1994: 310; Biber et al. 2000: 42). ${ }^{3}$

What cohesive means the speaker/writer will use, depends on his semantic, syntactic and socio-cultural knowledge. However, his choice must depend on the conventionalized expectations of the listener/reader, as the evaluation of the speaker's/writer's communicative effectiveness is based also on how the listener's/reader's expectations are implemented. It is also important to notice, that cohesive means do not themselves create meaning, but are only "clues used by speakers and hearers to find the meaning that underlies surface utterances" (Schiffrin 1987: 9).

When reviewing the research on textual cohesion, we can see, that there exist different classifications of cohesive means. Let us present only three of them. The most known is, of course, Halliday and Hasan's classification into: reference (personal, demonstrative, comparative), substitution, ellipsis, conjunction and lexical cohesion (Halliday and Hasan, 1976, Halliday 1994: 308-339).

\footnotetext{
${ }^{2}$ Important means of coherence in spontaneous conversations are also spontaneous completions and polyphonic talk. More about means of coherence see in Zuljan Kumar 2007.

${ }^{3}$ Cohesive ties are thus those ties which are expressed through lexico-grammatical means and "are meant to ease the hearer's job of trying to fit new information into his stack of old information" (Bublitz and Lenk 1999, 165; in Bublitz 1999).
} 
The second one is Beaugrande and Dressler's classification, which comprises: recurrences, parallelism, paraphrases, pro-forms (pro-nouns, pro-modifier such, pro-verbs, pro-adverbs), ellipsis, junction, tense, aspect, functional sentence perspective and intonation (Beaugrande, Dressler et al. 1992).

The third one is Quirk's classification which distinguishes between six groups of cohesive means: pragmatic and semantic implication, prosody and punctuation, lexical linkage and grammatical means (Quirk 1999).

However, when having reviewed the three classifications in detail, it turned out, that they do not differ from each other in the choice of cohesive means themselves, but mostly in the ways they are grouped, and, secondly, in their names, e.g. Halliday and Hasan's term lexical cohesion includes cohesive means which are in Beaugrande and Dressler's classification gathered in the groups recurrences and paraphrases, and in Quirk's classification in the group lexical linkage. Halliday and Hasan's group of referential means includes mostly cohesive means which are in Beaugrande and Dressler's classification called pro-forms, and in Quirk's classification mostly belong to the group of pragmatic and semantic implication.

I myself have decided to choose the Beaugrande and Dressler's classification, which, in my opinion, seemed the most clear and systematic of all three. However, through the analysis of cohesive means in my recorded spontaneous spoken conversations, I realized that by far the most frequent cohesive means used were those expressing co-reference. ${ }^{4}$ Therefore, in order to make the analysis of cohesive means as clear and transparent as possible, I made another classification in which I put all co-reference expressions together into one group to see how they form co-reference chains, which, as it turned out through the analysis, formed by far the most frequently used manner of expressing textual cohesion and thus also textual coherence. My principal goal thus was to form a classification of cohesive means which would be appropriate for the analysis of cohesive means in spoken texts. ${ }^{5}$ But as I found out later, there was another classification of cohesive means made and it was made for the analysis of cohesive means in Slovenian newspaper articles. Although the two classifications differ to some extent in other categories, they both have all co-reference means in one group. This probably points out, that co-reference means are the most important cohesive means in spoken a well as written Slovenian texts. Of course, one of the main differences between them is, that in spoken Slovenian

\footnotetext{
${ }^{4}$ Co-reference means endophoric (textual) reference and differs from exoforic (situational) reference.

${ }^{5}$ As it is well known from empirical investigations the use of lexico-grammatical means differs markedly from register to register and especially from written to spoken registers. While conversations are directly interactive, which means, that they are characterized grammatically by frequent use of the first and second personal pronouns, the three other major registers (fiction, academic prose, news) are not directly interactive and are thus not directed to any individual reader (see also Biber et al. 2000: 13-17).
} 
texts the use of pronouns in their explicit as well as zero form is much higher than in newspaper articles. ${ }^{6}$

My classification thus comprises: co-reference means: pronouns and ellipsis of pronouns, recurrences, partial recurrences and lexical relations (synonyms, antonyms, hypernyms, hyponyms, collocations and paraphrase); ellipsis, parallelism, discourse markers, prosody, functional sentence perspective, ${ }^{7}$ verbal aspect (perfective, imperfective), tense and intonation.

Due to the limitation in space, only three types of cohesive means will be analyzed in the following sections, i.e.: co-reference means: ellipsis of pronouns, recurrences, partial recurrences and lexical relations (synonyms, antonyms, hypernyms, hyponyms, collocations and paraphrase); ellipsis and parallelism.

But before starting the analysis of cohesive means in Slovenian spontaneous dialectal conversations, it is important to notice that cohesive means are not sufficient for asserting that a text is coherent. ${ }^{8}$ To prove this statement, we could take an example from any register of language (written or spoken, e.g. academic prose, newspaper article or casual talk), but let me take the example from poetry. ${ }^{9}$

The warring clouds have vanished from the skies;

The war of men has ended with the night.

The morning sun gilds the tree heads that rise

${ }^{6}$ See Bucik 2001.

${ }^{7}$ Slovenian is an inflectional language with a relatively free word order compared to the analytical type languages. In the latter the grammatical principle of word order is much stronger than in inflectional languages. In analytical languages in sentences with unmarked word order the leftmost position itself prototypically marks the theme and the rightmost position itself marks the focus. In Slovenian the position of individual items in the hierarchy of functional sentence perspective is determined by linguistic context, while in analytical type languages it is much more dependent on the syntactical roles of individual items in a sentence structure (See also Sgal 2006 and Zuljan Kumar 2009).

${ }^{8}$ We can take an example of a text which has no cohesive means, but is nevertheless coherent.

The baby is crying all the time. Tina being too tired does not have enough milk. Although there are no explicit cohesive ties between the two sentences, a reader/or listener can assume, that the text is coherent under the condition, of course, that he inferes the proposition Tina is the baby's mother who, probably because of her tiredness, has lost milk.

On the other hand, we can take an example of "a text" which includes cohesive means, but is not coherent.

I saw Urška's new bike. A bike is a noun. Nouns, adjectives and adverbs are parts of speech.

Although the above utterances include recurrences as an important means of establishing textual cohesion and coherence, they do not represent a semantic unit and are thus not coherent.

${ }^{9}$ The poem entittled "The Baptism" is an excerpt from the epic The Baptism at The Savica, written by France Prešeren and translated by: Alasdair Mackinnon (Prešeren 2000). 
Supreme above the Carniola's snowpeaks white:

The lake of Bohinj calm in stillness lies,

No sign of strife remains to outward sight;

Yet in the lake the fierce pike never sleep,

nor other fell marauders of the deep.

Is not this lake upon whose bank you stand,

Brave Crtomir, the image of your soul?

The clash of arms has ceased throughout the land,

Yet in your breast the storms of war still roll.

If aught of life's dire ills I understand

The eternal worm takes yet more deadly toll,

Battens on lifeblood in its inner lair

And reawakes the harpies of despair.

The text includes several types of cohesive means, ${ }^{10}$ but they are not sufficient to build textual coherence, because textual coherence depends also on the listener's/reader's encyclopedic knowledge. So, in order to establish coherence of the poem, he has to know the theme of the poem (who Črtomir is, what he represents, what the metaphore the three peaks means etc.) and the historical background about the struggle of the Slavic pagans in the territory of nowaday Slovenia who refused to accept Christianity and defended the Slavic Gods.

\section{Data and methodological approach}

The research on textual cohesion in spoken conversations is based on the six sociolinguistic interviews ${ }^{11}$ recorded in the Brda (The Hills), the region of low rounded hills with vineyards and fruit gardens situated in the far west of Slovenia, on the Slovenian-Italian-Friulian national and linguistic border. The language spoken there is called the Briško dialect. My informants were seven elderly inhabitants of the Brda, born between the years 1909 and 1938. They were chosen mainly from two reasons, first, their idiolects are not so much under the influence of either the literal Slovenian or literal Italian language (although this is not the rule), compared to the idiolects of the younger generations, because they either do not have any formal education or they went to the Italian schools, as the western part of the Slovenian territory (the so-called Primorska region) belonged to Italy until the end of the WW 2 (a part of the Primorska region, where there is the Slovenian minority, still belongs to Italy), and, second, because of their rich life experience. The informants are either my relatives or my family's friends whom I know well. Before starting to record, I

${ }^{10}$ There are three main co-reference chains, i.e.: 1. the war of men - the clash of arms; 2. the three heads - the Carniola's snowpeaks white; 3. the lake of Bohinj-the lake - this lake upon whose bank ...; a reference chain: you - Črtomir - your breast; discourse markers: yet, if, nor, and; antonyms: the night - the morning.

${ }^{11}$ The transcribed texts comprise around 25.000 words. 
explained them, that I wanted them to tell me and the other participant(s) their life stories. They were always in two or three together, they knew each other well and commented on the each other's stories, corrected each other with certain data, told their views of some event etc., while myself as a much younger participant asked questions, if I did not understand something and expressed different emotions at hearing about certain events.

\section{Cohesive means in Slovenian spontaneous dialectal conversations}

\subsection{Co-reference}

Co-reference is the relation between two linguistic items with the same reference (Gorjanc 1999: 142). A co-reference means can be any lexical item with co-reference potential, i.e. with the so-called ability to signal co-reference relation. Co-reference means helps us find the necessary piece of information for the interpretation of a linguistic item in the textual context. The ability of co-reference means therefore lies in its signaling co-reference relation (Halliday and Hasan 1976: 27-28). The condition, under which co-reference will be established, is that the co-referent which is being referred to, can be identified in the textual context (ibid: 11).

\subsubsection{Anaphoric co-reference}

The most common form of cohesive tie is "referring backwards". Anaphoric co-reference is used frequently in face-to-face communication (Biber et. al. 2000: 266) ${ }^{12}$ as can be seen from the analyzed Slovenian dialectal conversations. See examples [3], [6] and [8] below.

\subsubsection{Cataphoric co-reference}

Cataphoric co-reference is, compared to its frequency in academic prose and news reporting, rarely in use in conversations (ibid: 237, 267). ${ }^{13}$ Also in the

${ }^{12}$ According to Biber's research, the predominant type of reference in conversational texts is situational reference, then follows linguistic reference (or co-reference). This is mainly so, because in conversations "speakers make frequent reference to themselves, describing their own personal thoughts, feelings, past and present activities" (Biber et al. 2000: 11).

${ }^{13}$ According to Biber, the high frequency of cataphoric co-reference in academic prose and news reporting is connected with the complexity of the noun phrases used. On the other hand, its low frequency in conversations reflects "the simplicity of noun phrases" in face-to-face communication (Biber et al. 2000: 267). 
analyzed dialectal conversations, cataphoric reference was not frequently used, however, some examples have been found. Here two of them are presented in examples [1] and [2].

Context: Rudi Zuljan is telling Danila, how his family, when he was a young boy, used to prepare the so-called prunele, plums, that were peeled and put together in pairs, dried on a drying frame and then sold as dried fruit.

\section{Example [1]}

RZ: 'Tisste 'čirašpe, 'kardar sa bli pa kon'ča:ne, sa si k'lircli, sa jan 're:kli po slo've:nsko pru'ne:le. аәə Ja blo pa t'ri:aba tə'ku:a. ${ }^{14}$ 'ti:stu 'čirašpu o'lu:pat, 'lo:šst na pi'co:n /.../

RZ: Those plums, when they were finished, they were called, they called them in Slovenian prunele. əəə $\mathrm{We}$ had (to do) so: peel that plum, put it on a drying frame /.../

Context: In 1921 Stanko Pulec was called up to the Italian army. Their superiors counted them up by reading their surnames. When they came to the surnames of the Slovenian soldiers, they did not know how to pronounce them. Therefore, they just asked, if they were all there.

\section{Example [2]}

SP: 'Ka:dar sa k'lircli, ra'ci:mo, to'ku: sa b'ra:l, 'ne:, Tere'ži:ni, D'zi:ndzi, úsa: p'rii:mke, 'po:le sa 'pa:ršli do nas, sa 're:kli, s'je:te 'tuiti, sta un'si:? Ki 'nissa z'na:l /...l

D: 'A:, 'ja:, 'ja:, 'ja: 'Nissa z'na:l preb'ra:t, 'ne:.

SP: 'Ja:, 'Birzjak, 'ner, S'ta:nič an 'tarke, Med'veišček, 'ner.

D: (smeh)

SP: When they counted us up, let's say, they were reading so: Terezini, Zinzi, all surnames, then they came to us, they said, siete tutti, are you all here? Because they didn't know how to /.../

D: Oh, yeah, yeah, yeah, yeah, they didn't know how to pronounce your names, right?

SP: Yeah, Bizjak, right, Stanič and such, Medvešček, right?

D: (laugh)

\subsection{Co-reference means}

\subsubsection{Ellipsis of pronouns}

In English conversations the overwhelming majority of anaphoric expressions are pronouns (Biber et al. 2000: 238). In Slovenian it is different due to the linguistic rule, according to which pronouns in the nominative case have to be elliptical when the necessary grammatical information is encoded in the ver-

${ }^{14}$ The verb narediti (to do) is elliptical. See non-systemic ellipsis (section 4.2). 
bal suffix used. Therefore, the majority of anaphoric expressions in Slovenian conversational texts are formed by elliptical pronouns. ${ }^{15}$

Context: Stanko Srebrnič speaks about the priest who wanted to hear the band to check, if it is good enough for playing at a village ceremony.

\section{Example [3]}

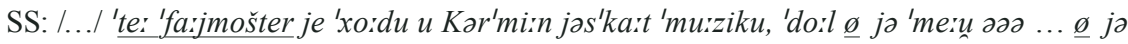

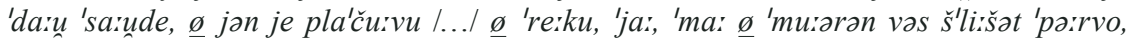

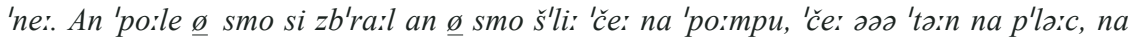
do'la:nji p'larc, ka'ku:a 're:čci, 'ta:n, 'čizaka ja 'li:pa. 'Ta:n pot 'ti:sti 'li:pi ja 'parršsu 'ti:st 'fa:jmošter an $\underline{\text { ja }}$ pošllu:šsu.

SS: That priest used to call the band from Cormons, ${ }^{16}$ there he had əəə, he used to give them some money, he paid them, right, /.../ He said, but I have to hear how how you play first, right. And then we gathered and we went to the pump, there to the borough, to the lower borough, how is it called, where there is a lime (tree). There under that lime came that priest and he listened to us.

\subsubsection{Recurrences}

In spontaneous speech recurrences and partial recurrences are a frequent co-reference means. It is so, mainly because the planning time in spoken conversations is short, and, secondly, because the surface text disappears from the interlocutors' working memories (Beaugrand, Dressler et al. 1992: 46). However, there is an important condition under which the establishment of textual cohesion through the use of recurrences and partial recurrences will be successful: the co-referent item and its antecedent have to refer to the same entity. If the co-referent refers to a different entity, regardless of the repetition of the same lexeme, co-reference fails to be established. In the following example the establishment of co-reference fails, because the repeated first name and its first mention do not correlate. Manca's laughter represents a clear signal of her awareness, that Gašper failed to establish co-reference. And continues Oh, Gašper, help me first find Simba by stressing the lexeme Simba, meaning 'my rabbit'.

${ }^{15}$ It is mainly so, because participants of face-to-face communication share the same physical context and usually a great amount of common knowledge which means, that the referents do not need detailed specification. They can be referred to by elliptical pronouns. Consequently, lower use of nouns brings less competition between potential referents which again consequently means, that elliptical pronouns are precise enough to identify a referent (See Biber et. al. 2000: 238). Moreover, if the reference established by an elliptical pronoun is unclear to the participants, they can immediately ask the speaker and clarify who or what the elliptical pronoun refers to.

${ }^{16}$ Cormons/Krmin is a small Friulian town $6 \mathrm{~km}$ from the Slovenian village of Medana. 
Context: Manca and her cousin Gašper are playing in a living room. Mother asks Manca, where her rabbit is, while Gašper thinks his aunt is asking about the videocassette The Lion King, in which the lion cub, called Simba is the main protagonist.

\section{Example [4]}

Mama: Manca, čiz je Simba?

Gašper: Ja, ja, 'bo:mo $\gamma^{\prime l a: d l i ~ ' S i: m b u . ~}$

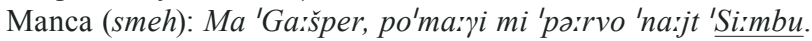

Mother: Manca, where is Simba?

Gašper: Yeah, yeah, we'll watch Simba.

Manca (laugh): Oh, Gašper, help me find Simba first.

\subsubsection{Partial recurrence}

The term partial recurrence refers to the use of the already activated expression, but in a different part of speech (Beaugrande, Dressler et al. 1992: 47). In example [5], when referring to meat they tried on their own at home, Helena uses the adjective bitter first and then the noun bitterness.

Context: In the Brda, pork meat is air-dried. In the past there was a small room in the cellar which was the coldest space in the house used especially for drying meat. However, if the summer was very hot, it got hot also in the cellar, which consequently meant that the drying meat became bitter. In the following excerpt of the text Danila is interested in where the cellar with the special room for drying meat was situated in the house.

\section{Example [5]}

D: An 'čira bla 'ta: k'liat?

H: 'Bu:j u 'ta:mnan k'ra:ju, f'ri:šnan, 'sa:mo ja 'ra:tlo [svinjsko meso] k'lu:p 'te:mu y'ra:nko. An usakantar'ka:j so 'bu:ayi o'čistal 'do:l 'ti:stu yran'či:nu /.../

D: And where was that cellar?

$\mathrm{H}$ : Somewhere in a darker place, colder, but nevertheless it [the pork meat] became bitter. And from time to time poor people cleaned that bitterness up /.../

\subsubsection{Lexical relations}

\subsubsection{Synonyms}

Synonyms are more common in written registers ${ }^{17}$ than in conversations (Biber et al. 2000: 238). There are probably several reasons for that. One of them is

\footnotetext{
${ }^{17}$ Especially in fiction where a great diversity of vocabulary is highly appreciated.
} 
the lack of planning time in face-to-face communication, the other would be, that speakers know each other and probably also the referents, they are talking about. However, in conversations synonymy is usually used when one of the speakers does not know the meaning of the referring expression. In this case clarification is needed and it can be performed also by the use of a synonymous lexeme, as in the example [6].

Context: For every kapelška nedelja, the first Sunday after Easter, Anči and her friends used to go to Vrhovlje, a village, fifteen kilometers away from where they lived, on foot to hear mass. Due to a long way, they used to take some snack and a drink. Once Anči's brother secretly took food out of the bag and changed it with a dried swine's head. The girls did not notice any change. But after some time walking up the hill, Anči started complaining how heavy the bag was. They sat down and to their surprise they found out what Anči's brother had done.

Danila did not understand the dialectal lexeme Anči used, so she explained it with another dialectal synonymous lexeme. Although Anči used the lexemes krepa and glava as synonyms, they are not completely interchangeable. The lexeme glava is a neutral Slovenian expression for a head, while krepa is a loan word from Italian/Friulian, meaning a scull of an animal, pejoratively used also for people.

\section{Example [6]}

AV: /.../ O'do:pre 'tirst ta'va:lč, otk'ri:je, jo bla 'no:tar na k're:pa ot sva'na:ta. Ma'ri:ja, ma'ri:ja, ma'rija.

D: (vprašujoč pogled)

AV: K're:pa ot sva'na:ta, 'tura bi bla 'a:dna r'la:va ot ot ot ot p'ra:sca.

$\mathrm{AV}: / .$. / She [Anči's friend] uncovers that cloth, beneath there was krepa od svenata (a skull of a pig), for Christ's sake.

D: (rises her eyebrow as a sign that she does not understand)

A: Krepa od svenata would be a head of of of a swine.

\subsubsection{Collocations}

In collocations textual cohesion is not expressed through lexical relationships of synomymy or antonymy, but through associative relationship which includes expectation: due to the presence of one lexeme, it is expected, that another one will occur (Halliday 1994: 333).

In our example Danila is asking Rudi about the fruit they grew on his farm, and he immediately mentions vegetables.

\section{Example [7]}

D: An 'ka:ko 'sa:dje sta 'mi:al 'te:kart?

R: 'Sa:dje blo 'ti:ste, ki je 'da:nas, 'na:rvač je blo če'rirašan, ne, ki sa prat'se:n ot ča'rirašan ži'vi:alo, da na yuə'ri:mo od zelen'ja:ve. 
D: And what fruit did you have at that time?

$\mathrm{R}$ : The sorts of fruit were the same as today. There were many cherries, because we lived mainly on cherries, not speaking of vegetables.

\subsubsection{Paraphrase}

Paraphrasing means repeating the same content in a different expression (Beaugrande, Dressler et al. 1992: 48) or in Parret's words: "Paraphrasing is [...] an operation which consists of producing, within the conversation, a unit, which is semantically equivalent to another unit previously mentioned" (Parret 1989: 288). The willingness to paraphrase represents one of the main cooperative strategies between interlocutors with the purpose of clearing up or clarifying any incomprehensibility or misunderstanding. It is therefore an important coherence principle in conversation (ibid.).

In example [8] Stanko being aware of Danila's not understanding the metaphorical meaning of the lexeme škrtoc, uses a paraphrase to clarify it.

Context: Stanko Srebrnič is explaining to Danila how all recruits were scared to death of not getting the medical certificate, because this meant, that they were not healthy enough to be recruited. And if they were not able to go to army, their colleagues and girls called them škrtoci (literally paper bags), in metaphorical sense meaning they were not esteemed among their peers any more.

\section{Example [8]}

SS: Sa'virade, u'sa:k a 'mi:au st'ra:x, do 'na: mu po're:či, da da na bi 'bi: škor'to:c. 'Ki: škar'to:c po'mi:ane, da'po:le 'na:č na va'ja:šs. Ku'niss bi vo'ja:k, sa ti ứsa: 'pu:pe si sma'ja:l.

SS: Of course, everybody was afraid of being called škrtoc. Because škrtoc means that you are worth nothing. If you were not a soldier everybody laughed at you.

In example [9] Rudi needs to describe first how a drying frame they used for drying fruit was made and then clarifies what the verb penčati means.

Context: Danila is asking Rudi, what they did in their family, besides producing wine, to get extra money. He explains, they used to dry plums. Danila wonders, what tools they used for drying and what the process of drying looked like. Rudi tells her, they used a special drying frame, explains what it looked like, and then he describes, how they put plums together in pairs and called them prunele.

\section{Example [9]}

RZ: Pi'co:n smo 're:kli ...je 'bi:u 'ta:k ... sa bli d'va: 'ri:mənla, prib'li:žno d'va: 'me:tra

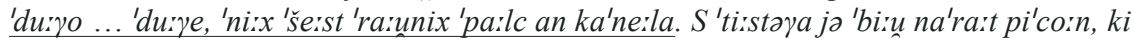
sa 'po:le 'lo:žlo 'ši:t 'čirašpe 'yo:r, 'ner. Kar sa b'li: 'ti:ste 'či:ašpe 'su:xe, sa ... smo 'mo:yli u'za:t kos'ti: 'u:an z u'sa:ke an smo k'la:dli d'vira an d'vi:a u'ko:p. Ta'ku:a sa tisstu 'riač, smo 're:kli, pan'ča:lo. 
RZ: A drying frame was ... it was a kind of a ... there were two planks around two metres long, six flat boards and reed. That was what a drying frame was made of that plums were being dried on, right? When those plums were dry, they ... we took stones out from each and put two and two together. That's how we ... as we said ... penčali that thing.

\subsubsection{Antonyms, hypernyms and hyponyms}

The frequency of antonyms, hypernyms and hyponyms, compared to the frequency of personal pronouns and recurrences in the analyzed texts, was low. The shared situation and personal involvement of interlocutors result, as mentioned before, in a dense use of pronouns or their elliptical forms and not nouns. Besides, searching for an antonym, a hypernym or a hyponym in his working memory requires from a speaker a longer planning time and in conversations the planning time is, compared to other registers, very short. Moreover, hypernyms and hyponyms offer detailed and precise descriptions of the entity referred to, which are in usual, everyday conversations not needed.

In the analyzed texts antonymy were mainly used when the speaker wanted to point out the opposition between the two parts of a sentence, like in the example [10], while hypernyms and hyponyms were used when further explication was needed, as shows the example [11].

Context: Lojz is narrating about his job in the cellar. He says he was honest when he weighed the grapes the farmers carried to the cellar.

\section{Example [10]}

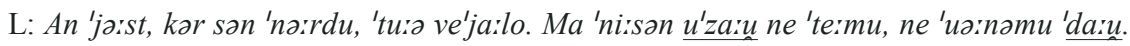

L: And what I did, everybody agreed. Because I neither took from the one nor gave to the other one.

Context: The choir members from Medana could hardly wait for the dinner the priest organized once a year for the church choir.

\section{Example [11]}

AV: In smo 'ča:kli, 'ka:t bo 'tista vi'čerrja. 'Ta:ke f'ri:tule 'diralla 'ku:xərca, gu'ba:ncu, 'ki: da'ma: 'ni:smo 'miral an'ko:l 'narč. (smeh) 'Tura b'lor ... 'sa:mo 'sa:mo pu'le:ntu smo 'ja:dli da'ma: an 'to:nfu (smeh) s kram'pi:arja.

AV: And we were waiting, when there would be that dinner. The cook made such donuts, a nut roll, cause we had nothing at home (laugh). There it was ... We ate only only maize porridge at home and tonfa ${ }^{18}$ (laugh) with potatoes.

${ }^{18}$ Tonfa 'a kind of goulash made of mashed potatoes'. Maybe $<$ friul. a toffo 'finely ground maize flour'. 


\section{Ellipsis}

Ellipsis means the omission of elements which are recoverable or inferable from the context. An elliptical structure in this sense means a sequence of words in which some words have been omitted. Unlike reference, which is a semantic relationship, ellipsis sets up a relationship in wording, i.e. lexicogrammatical relationship (Halliday 1994: 316). The omitted elements can be added to the sentence without changing its meaning and without producing ungrammatical structure. According to its use in spoken language, we can distinguish between systemic and non-systemic ellipsis.

\subsection{Systemic ellipsis}

Systemic ellipsis occurs in written and spoken language and is subject to the linguistic rules of a language (linguistic system). One type of systemic ellipsis belonging to this group is the ellipsis of a personal pronoun in the function of a subject when the necessary information for the identification of the referent is encoded in the predicate's ending in the standard Slovenian language. Another type of systemic ellipsis is ellipsis in question-answer sequences and other rejoinder sequences. It is a standard pattern in face-to-face communication in many languages and forms a frequently used type of cohesive relation. Here are some examples from our dialectal texts.

Context: Helena and Marija are telling Danila how they used to prepare potica in their family when they were little girls. ${ }^{19}$

\section{Example [12]}

D: /.../ ru'ba:nca b'la: pa bo'ya:ta 'te:kart, 'ne:?

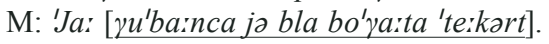

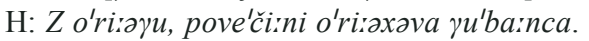

D: Ma sta 'mi:al 'ma:kinju za m'li:at [o'ri:axe]?

H: 'Ner, 'ne: ['ni:smo 'mi:al 'ma:kinje za m'liat o'riaxe].

$\mathrm{D}: / . . /$ gubanca ${ }^{20}$ was rich at that time, right?

M: Yeah [gubanca was rich at that time].

H: With nuts, mostly with nuts.

D: And did you have a machine for grinding [nuts]?

H: No, no [we didn't have a machine for grinding nuts].

${ }^{19}$ The elliptical parts of a text are in brackets and underlined.

${ }^{20}$ Gubanca in the briško dialect or gubana in Italian and Friulian is a cake consisting of a sheet of pastry spread with a rich filling and rolled up. It is a typical Slovenian national dish, usually baked for the most important religious (Christmas and Eastern) and personal feasts (anniversary, marriage). In the Primorska region it is usually filled with nuts and raisins. 
In the analyzed texts a frequently used type of elliptical structure is that in elliptical yes/no questions with the pragmatic function of an offered response, as shown in example [13].

Context: Danila is interested in how eggs were prepared in the past in the Brda region. Beside a WH-question, she asks also an elliptical yes/no question (Fried?) which is in the function of one of the possible responses. By repeating the lexeme, Helena and Marija answer in the affirmative. In the utterance 3 Danila offers another response, again in the form of the elliptical yes/no question. Repeating the lexemes from the utterances 1 and 3, Helena confirms Danila's offered answer by elaborating the elliptical lexeme eggs (in lettuce) and by adding another way of preparing them (and cvrča). ${ }^{21}$ Danila's elliptical question ( $C v r \check{c} a$ ? ) in the following utterance does not have the pragmatic function of an offered answer; it is the elliptical wh-question. This can be seen in her next question (What is this?) which anaphorically refers to cvrča.

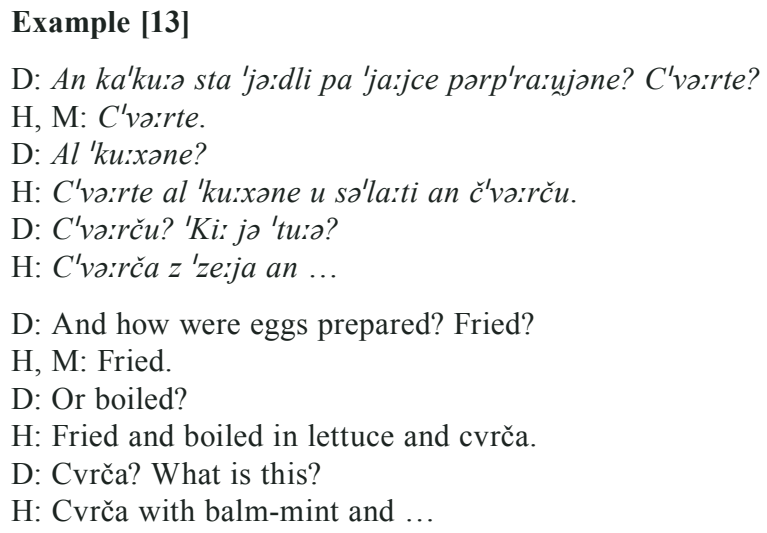

\subsection{Non-systemic ellipsis}

Non-systemic ellipsis is typical of spoken language. ${ }^{22}$ It is not subject to the grammatical rules; on the contrary, it violates them. However, the omitted elements are recoverable or inferable from the context. There are two reasons for this phenomenon: 1. the lack of planning time on the part of the speaker, 2. the speaker thinks the omitted element is present in discourse without being explicitly mentioned. In example [14] the head of the prepositional phrase, i.e. at that (hour) and the head of the nominal phrase, i.e. the second (turn) are omitted, nevertheless, this does not affect textual coherence, because the

${ }^{21}$ Another more frequently used word for $c v r c ̌ a$ is frtalja which is a loan word from Friulian. Cvrča is a dish typical of the Brda region made of scrambled eggs with herbs typical of this region.

${ }^{22}$ Although it can be used also in written registers, e.g. in spoken dialogues in fiction. 
notions can be recovered from the context as well as inferred from common (mutual) knowledge of the interlocutors (both; Danila and Pepi know that turns are associated with hours).

Context: Pepi speaks about his job in the bakery.

\section{Example [14]}

P: Smo b'li: ... 'mi:al po t'ri: 'tu:rne. ${ }^{23}$ 'A:dan op 'ta:ki ('urri) 'a:dan op 'ta:ki ('urri).

D: An ča ste 'di:alu po'no:č, 'ka:t ste 'šu:?

P: Kur ja 'ra:tlo, po'norč, ot ot 'šeste z'verčar do 'a:dne popuno'čir: Ob 'a:dni popuno'či:

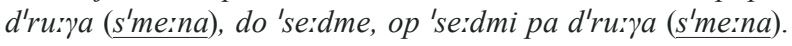

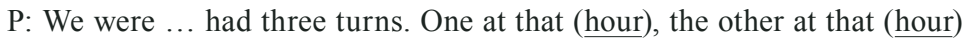

D: What about at night? When did you start?

P: Well, it was not always the same, from from six in the evening till one. At one the second (turn) and at seven the third (turn).

\section{Parallelism}

Parallelism means the repetition of equal syntactic structures with different content. In analyzed excerpt [15] parallel structures were used after the cataphoric $s o$ in order to illustrate, how dancing parties were organized in different villages. By creating parallel structures, Stanko in fact reinforces the similarities in their meanings. We can therefore say, that parallelism has a strong connective potential in his speech. Besides emphasizing the likeness of content, i.e. how dancing parties were organized throughout the year in different villages, parallel structures also add cohesive force to the text.

Context: Stanko is explaining how young people organized dancing parties in the Brda. It was important for every village to organize an event and not to overlap with other villages.

\section{Example [15]}

SS: U ún'sa:ki 'varsi blo tə'ku:ə; əəə Mo'da:na a 'mi:ala au'guista, ku sən 're:ku žə p'ri:ət, Ślma:rtno a 'mi:alo na ka'pe:lšku, par'ca:jtu, ža 'parrvu na'di:aju po va'li:ki 'no:či, $\underline{u}$ 'Ni:ablan sa 'mi:al 'ju:lja an ta'ku:a nap'ri:, u'sa:ka 'va:s a 'mi:ala 'so:ju na'va:du.

SS: In every village it was so (organized): əəə Medana had (a dance) in August, as I said before, Šmartno had (a dance) on the kapelška ${ }^{24}$ Sunday, early, the first Sunday after Easter, Neblo had (a dance) in July and so on. Every village had its own habit.

${ }^{23}$ In the first two utterances the speaker uses the loan word turn from Italian (turno) or Friulian (turni), then, in the following utterances he continues with the Slovenian lexeme izmena, which is in the Brda dialect synonymious to the lexeme turn. Although the lexeme izmena as the head of the nominal phrase is elliptical, the change can be seen from the change is gender; the premodifier druga has the feminine ending - $a$, while the lexeme turn is masculine.

${ }^{24}$ The first Sunday after Easter. 


\section{Conclusion}

To summarize, cohesive ties represent the important device of establishing and maintaining textual coherence. However, the use of cohesive means in spontaneous spoken conversations differs to some extent from the use of cohesive means in written registers. Partly, this is to do with the shared situation of the interlocutors and partly, with the shortness of planning time in conversations, compared to its length in written registers. Although in literature one can find several classifications of cohesive means, I have tried to present in my paper my own classification, which to some extent differs from other classifications and would, in my opinion, help analyze, in a clear and systemic way, the cohesive means in Slovenian spontaneous spoken (dialectal) texts. In my classification I put all co-reference expressions into one group and indicated, how they build co-reference chains, which, as it turned out, were the most frequently used manner of establishing textual cohesion (and consequently, also textual coherence). Beside co-reference means, I analyzed also the use of ellipsis and parallelism. The three categories were chosen mainly from three reasons: first, they were the most salient and in the case of elliptical pronouns, recurrences and systemic and non-systemic ellipsis the most numerous among all cohesive means, second, I dealt with the use of functional sentence perspective and discourse markers in dialectal conversations in other articles, and third, I was limited in space.

The further results of the research may be summed up as follows:

The research has shown, that the most frequently used co-reference means were elliptical pronouns (pronouns in Slovenian have to be elliptical when the necessary grammatical information is encoded in the verbal suffix used), which are heavily situation-dependent. Participants of a conversation share the same physical context and a great deal of common knowledge.

Moreover, the research has shown, that because of a low frequency of nouns in conversations there is less competition between potential referents and thus, again, pronouns substitute lexical relations (synonyms, antonyms etc.).

The second most frequently used co-reference means were recurrences. The repetition of a linguistic item requires a shorter planning time as, for example, searching for a synonym or a hypernym. Speakers usually used collocations when they were associatively related to the topic of the conversation and, using them, they sometimes drifted off the intended topic.

Paraphrases were used in order to clear up potential misunderstanding.

Antonyms, hypernyms and hyponyms were the least frequently used coreference means. Antonyms were mainly used for the purpose of expressing explicit opposition; while hypernyms and hyponyms were used when further explication, e.g. to clear up misunderstanding, was needed.

Besides systemic ellipsis (e.g. in question-answer sequences, which is typical of spoken language), non-systemic ellipsis, which is not subject to grammatical rules, was used very often. However, this did not affect textual coherence, because the omitted parts of the sentences were either recoverable from the context or inferred from common knowledge of the interlocutors. 
The third most frequently used type of cohesive means was parallelism. In the analyzed texts the function of parallel structures was to reinforce the similarities in their meanings. Parallel structures were also used in negotiations among the speakers in order to prove they were right in their statements.

\section{LITERATURE}

Robert de BEAUGRANDE, Wolfgang Ulrich DRESSLER, Aleksandra DERGANC, Tjaša MIKLIČ, 1992: Uvod v besediloslovje. Introduction to Text Linguistics. Ljubljana: Park.

Douglas BIBER, Stig JOHANSSON, Geoffrey LEECH, Susan CONRAD, Edward FINEGAN, 2000: The Longman Grammar of Spoken and Written English. Harlow: Longman.

Wolfram BUBLITZ, 1999: Introduction: Views of Coherence. Coherence in Spoken and Written Discourse: how to create it and how to describe it. Eds. W. Bublitz et al. Amsterdam, Philadelphia: Benjamins.1-7.

Wolfram BUBLITZ, Uta LENK, 1999: Disturbed Coherence: Fill me in. Coherence in Spoken and Written Discourse: how to create it and how to describe it. Eds. W. BUBLITZ et al. Amsterdam, Philadelphia: Benjamins.153-174.

Ksenija BUCIK, 2001: Strukture kohezije. Strukture koreferenc in tematske progresije. Structures of Cohesion. Structures of Co-references and Functional Sentence Perspective. Diplomsko delo (mentor: prof. dr. Marko Stabej). Ljubljana: Filozofska fakulteta. Oddelek za slovanske jezike in književnosti.

Vojko GORJANC, 1999: Kohezivni vzorec matematičnih besedil. Coherence Pattern of Mathematic Texts. Slavistična revija 47/2. 139-159.

M. A. K. HALliDAY, Ruqaiya HASAN, 1976: Cohesion in English. London and New York: Longman.

M. A. K HALLIDAY, 19942: An Introduction to Functional Grammar. London: Edward Arnold.

Herman PARRET, 1989: Paraphrase as a Coherence Principle in Conversation. Condizioni di coerenza: Ricerche di linguistica testuale, 1988. Eds. M.-E. Conte, J. S. Petöfi, E. Sözer. Firenze: "La nuova Italia" Editrice. 281-324.

France PREŠEREN, 2000: Poems (Translated by: Alasdair Mackinnon). Ljubljana: Založba Sanje. www.preseren.net/ang/3_poezije/100_krst.asp.

Randolph QUIRK, 199915: A Comprehensive Grammar of the English Language. Harlow, Essex: Longman.

Deborah SCHIFFRIN, 1987: Discourse Markers. Cambridge: Cambridge University Press.

Petr SGALL, 2006: Language in its Multifarious Aspects. Charles University in Prague: The Karolinum Press. 
Danila ZULJAN KUMAR, 2007: Narečni diskurz. Dialectal Discourse. Ljubljana: Založba ZRC.

- -, 2009: Členitev po aktualnosti v govorjenem narečnem besedilu. Functional Sentence Perspective in Spoken Dialectal Text. Obdobja 26. Slovenska narečja med sistemom in rabo. Ed. Vera Smole. Ljubljana: Filozofska fakulteta. Center za slovenščino kot drugi/tuji jezik. 187-201.

\section{KOHEZIVNA SREDSTVA V SLOVENSKIH SPONTANIH NAREČNIH POGOVORIH}

Kohezivna sredstva so slovnična in leksikalna sredstva, ki vzpostavljajo kohezijo besedila in tudi njegovo koherenco. Vendar kohezivna sredstva niso niti zadosten niti nujen pogoj za besedilno koherenco, kot avtorica prikaže na primeru pesemskega besedila. V nadaljevanju prispevek obravnava različne delitve kohezivnih sredstev, kot jih poznamo iz tuje literature, ter svojo lastno delitev kohezivnih sredstev, primerno za analizo kohezivnih sredstev v slovenskem govorjenem jeziku. $V$ tretjem delu avtorica obravnava rabo kohezivnih sredstev v spontanih narečnih slovenskih pogovorih. Podrobneje analizira rabo koreferenčnih sredstev, elipse in paralelizma. Koreferenčna sredstva so osnovno sredstvo vzpostavljanja besedilne kohezije v pogovoru. Najpogostejše koreferenčno sredstvo v slovenskih spontanih narečnih pogovorih je elipsa zaimka, saj so potrebne informacije za identifikacijo referenta vkodirane v glagolski obliki. Druga koreferenčna sredstva, ki jih (slovenski) govorec rabi, so še: ponovne pojavitve in delne ponovne pojavitve, ki so v spontanih pogovorih pogosto koreferenčno sredstvo zaradi pomanjkanja načrtovalnega časa, medleksemska razmerja, med katera štejemo so-, proti-, nad- in podpomenke, sopojavljanke (ki vključujejo t. i. sopojavitveno tendenco) ter parafraze. Pomembno sredstvo vzpostavljanja besedilne kohezije v obravnavanih pogovorih so bili izpusti, tako sistemski, to so tiste vrste izpusti, ki so podrejeni slovničnim pravilom jezika oziroma jezikovnega sistema, kot nesistemski, to je tiste vrste izpusti, ki jih govorec uporabi, kadar predvideva, da je referent $\mathrm{v}$ besedilu že prisoten oziroma se ga da iz sobesedila ali iz situacijskega konteksta prepoznati, ter paralelizmi. 